Paweł Ulman

Uniwersytet Papieski

Jana Pawła II w Krakowie
Kiedy myślimy Rodzina..., red. M. Duda,

K. Kutek-Sładek, Kraków 2016, s. 73-88

(Praca Socjalna w Teorii i Działaniu, 2).

\title{
Sytuacja ekonomiczna gospodarstw domowych w Polsce
}

\author{
The economic situation of Polish households
}

\begin{abstract}
The family is a special value to both society and individuals. Numerous risks of its functioning can be treated in the individual and social dimension. Among the many areas in which the family can experience the difficulties of everyday life is this referring to the material and financial security of its functioning. The aim of this paper is to point out
\end{abstract}

some aspects of family life risks in the area of economic functioning of the family. To achieve that purpose, the statistical data were drawn from the research "Social Diagnosis 2013".

Keywords: family, household, economic situation, poverty

Rodzina jest szczególną wartością w życiu zarówno społecznym, jak i poszczególnych ludzi. Zagrożenia dla jej funkcjonowania należy więc rozpatrywać jako problem indywidualny oraz problem społeczny. Problem indywidualny, ponieważ dotyczy poszczególnych członków społeczeństwa - ich wzrastania, rozwoju, szczęścia, samorealizacji i innych aspektów związanych z prowadzeniem wartościowego życia. Zagrożenie rodziny to również problem społeczny, bo z jednej strony dotyczy dużej rzeszy rodzin, które już doświadczają skutków owych złych oddziaływań na rodzinę, a z drugiej strony dotyczy przecież wszystkich innych rodzin, które są narażone na te oddziaływania.

Problem zagrożenia rodzin można rozpatrywać w dwojaki sposób. Po pierwsze, można wskazywać na potencjalne złe rozwiązania forsowane w ramach takiej czy innej polityki. W ten sposób można przeciwdziałać niepożądanym sy- 
tuacjom skutkującym zagrożeniem bezpieczeństwa rodziny w różnych jej wymiarach. Przykładem może być z jednej strony forsowanie, a z drugiej krytyka konwencji o przemocy w rodzinie. Po drugie, o zagrożeniu życia rodzinnego można wnioskować na podstawie obserwacji sytuacji zaistniałej w rodzinach. Wysoka częstotliwość występowania jakiegoś niepokojącego zjawiska wskazuje, że w otoczeniu życia rodzinnego występuje zagrożenie, któremu poddały się (uległy jej, doświadczyły) niektóre rodziny, co z kolei jest ostrzeżeniem dla innych rodzin czy osób. Ponadto, co może być istotne, percepcja danego zagrożenia niesie informację wpływającą na zachowania lub decyzje indywidualnych osób lub całych grup społecznych. Dobrym przykładem może być problem ubóstwa, którego doświadcza duża liczba rodzin, a zwłaszcza rodzin wielodzietnych. W świadomości społecznej powstaje więc obraz łączący wielodzietność z wysokim zagrożeniem ubóstwem. Nie można się więc dziwić, że wiele młodych małżeństw, chcąc zminimalizować tego typu zagrożenie, nie będzie dążyło do założenia rodziny wielodzietnej.

Wśród wielu obszarów, w których rodzina może doświadczać trudności życia codziennego, jest ten odnoszący się do materialnego i finansowego zabezpieczenia jej funkcjonowania. W tym obszarze na problem zagrożenia rodziny można spojrzeć $z$ dwóch stron. W pierwszym podejściu można rozpatrywać sytuację, gdy zagrożone jest właściwe funkcjonowanie rodziny z powodu niewystarczających środków finansowych, natomiast w drugim podejściu zagrożenie może wypływać z konsumpcyjnego podejścia do życia, które w większej mierze może dotyczyć rodzin o relatywnie wysokich dochodach. Celem niniejszej pracy jest wskazanie na wybrane aspekty zagrożenia życia rodzinnego w obszarze ekonomicznym funkcjonowania rodziny w pierwszym ze wskazanych wyżej ujęciu. Do realizacji wspomnianego celu wykorzystane zostaną dane statystyczne zaczerpnięte z badania „Diagnoza Społeczna 2013”.

\section{Definicja rodziny i gospodarstwa domowego}

Terminy „rodzina” oraz „gospodarstwo domowe” nie są tożsame, chociaż bardzo często odnoszą się do tej samej grupy osób. Zdefiniowanie wspomnianych pojęć jest istotne z punktu widzenia badania statystycznego, którego celem jest przedstawienie obrazu danej rzeczywistości w sposób liczbowy. Z kolei liczbowe ujęcie zjawisk wynika bezpośrednio z ich pomiaru. Łatwo można sobie wyobrazić, że różne ujęcia (definicje) tych samych zjawisk prowadzą do różnych wyników ich pomiaru, co w konsekwencji może skutkować zasadniczo różnymi wnioskami z przeprowadzonych analiz. W związku z powyższym poniżej zostanie przeprowadzony krótki przegląd definicji rodziny i gospodar- 
stwa domowego. Definiowanie gospodarstwa domowego w kontekście badań nad zagrożeniami życia rodzinnego jest uzasadnione w zakresie ekonomicznego aspektu funkcjonowania rodziny. Na gruncie ekonomii to właśnie gospodarstwo domowe, a nie rodzina jest podmiotem, który jest elementem systemu ekonomicznego.

Na potrzeby spisu powszechnego pojęcie rodziny w ujęciu biologicznym definiuje się jako dwie lub większą liczbę osób, które są związane jako mąż i żona, wspólnie żyjący partnerzy (kohabitanci) będący osobami płci przeciwnej lub jako rodzic i dziecko. Definicja ta uznaje więc za rodzinę parę osób dorosłych (związanych ślubem lub nie) bez dzieci, z dziećmi, jak również samotnego rodzica $z$ dzieckiem lub dziećmi ${ }^{1}$. GUS wyróżnia w tym przypadku następujące typy rodzin biologicznych: małżeństwo bez dzieci, małżeństwo z dziećmi; partnerzy bez dzieci lub z dziećmi oraz ojca lub matkę z dziećmi. Określa również rodzinę pełną i niepełną. Tę drugą stanowią samotni rodzice z dziećmi. Definiuje także rodzinę rozszerzoną jako rodzinę biologiczną wraz z co najmniej jedną osobą spokrewnioną z przynajmniej jednym członkiem rodziny. Natomiast za rodzinę młodą uważa taką, w której współmałżonkowie (kohabitanci) są co najwyżej w wieku: kobieta - 30 lat, mężczyzna - 35 lat ${ }^{2}$.

Na potrzeby swoich badań OECD używa definicji rodziny w gospodarstwie domowym, której źródło odnaleźć można w rekomendacji ONZ co do spisów powszechnych ${ }^{3}$. Rodzina jest tam definiowana jako ci członkowie gospodarstwa domowego, którzy są spokrewnieni ${ }^{4}$ do pewnego stopnia poprzez krew, adopcję lub małżeństwo. W dalszej części definicji wskazuje się, że niejednoznaczność określenia zakresu pojęcia rodzina wiąże się z możliwością pozyskania danych na jej temat w różnych społecznościach. ONZ w 1974 roku zapoczątkowała definiowanie pojęć rodzina i gospodarstwo domowe na potrzeby spisów powszechnych. Pierwotnie rodzinę łączono z instytucją małżeństwa. Jednak wraz ze zmianami społecznymi powoli zaczęto związki niemałżeńskie uważać za konstytuujące rodzinę. Ostatecznie zostało to formalnie określone w 1997 roku. Wtedy też przyjęto, że rodziną są samotni rodzice, którzy nigdy nie byli w związku małżeńskim. Jak pokazuje praktyka przeprowadzania spisów społecznych w różnych państwach, pojęcie rodziny nie jest całkowicie takie samo, co oczywiście prowadzi do braku możliwości porównywania danych

1 GUS, Gospodarstwa domowe i rodziny. Charakterystyka demograficzna. Narodowy Spis Powszechny Ludności i Mieszkań 2011, Warszawa 2014, s. 21.

2 Tamże, s. 21.

3 Principles and Recommendations for Population and Housing Censuses, Revision 1, United Nations, New York, 1998, para. 2.63.

4 W anglojęzycznej definicji zostało użyte słowo „related”, które należy rozumieć szerzej niż tylko pokrewieństwo, na co wskazuje dalsza część definicji. 
spisowych między narodami ${ }^{5}$. Nauczanie Kościoła wskazuje na ważność rodziny dla rozwoju człowieka i społeczeństwa jako wspólnoty. W encyklice Rerum novarum papież Leon XIII pisał, że rodzina jest prawdziwą społecznością i jest starsza od wszelkiego państwa ${ }^{6}$, natomiast Sobór Watykański II określił rodzinę jako „pierwszą i żywotną komórkę społeczeństwa”" Rozumienie słowa „rodzina” w dokumentach kościelnych związane jest ze wskazaniem fundamentu tego związku, jakim jest małżeństwo sakramentalne lub przynajmniej kanonicz$n e^{8}$, na którego bazie powstaje szersza komunia rodziny, rodziców i dzieci, braci i sióstr pomiędzy sobą, domowników i innych krewnych.

Gospodarstwo domowe w praktyce badań GUS-u definiowane jest jako „zespół osób spokrewnionych ze sobą lub niespokrewnionych, mieszkających razem i wspólnie się utrzymujących lub osoba utrzymując się samodzielnie, bez względu na to, czy mieszka sama, czy też z innymi osobami”" . W literaturze ekonomicznej gospodarstwo domowe określa się jako kluczową jednostkę w sferze konsumpcji, której podstawowym celem jest zaspokojenie jednostkowych i wspólnych potrzeb konsumpcyjnych członków gospodarstwa domowego poprzez wytwarzanie dochodu, jego podziału na różne cele, produkcję dóbr, świadczenie usług i gromadzenie zapasów ${ }^{10}$. $Z$ tego wynika, że gospodarstwo domowe można traktować również jako podmiot gospodarujący, wyodrębniony w sensie ekonomicznym, wypełniający funkcję produkcyjną oraz konsumpcyjną zgodnie z podjętymi w określonych warunkach społeczno-ekonomicznych decyzjami. Na podstawie szerokiego przeglądu definicji gospodarstwa domowego Tomasz Zalega zaproponował, aby za gospodarstwo domowe uważać autonomiczny podmiot gospodarujący, wyodrębniony w sensie ekonomicznym na podstawie własności osobistej, podejmujący decyzje w sferze konsumpcji w oparciu o własne subiektywne preferencje, upodobania, przyzwyczajenia i tradycje, a także istniejące ograniczenia obiektywne w celu maksymalnego i najbardziej racjonalnego zaspokojenia ogółu potrzeb wszystkich swoich członków ${ }^{11}$. Jak pokazuje przytoczona wcześniej definicja, wykorzystywana przez GUS w praktyce,

5 Więcej na ten temat można znaleźć w pracy: L. Hantrais, Bycie rodziną w Europie raport, Rządowa Rada Ludnościowa, Biuletyn 50, Warszawa 2006 s. 18-21.

6 Leon XIII, enc. Rerum novarum, nr 9.

Dekret o apostolstwie świeckich Apostolicam actuositatem, nr 11, [w:] Sobór Watykański II. Konstytucje, dekrety, deklaracje, Poznań 1986, s. 578-627.

8 Więcej nt. różnic między małżeństwem sakramentalnym a kanonicznym można znaleźć w pracy: P. Kroczek, Wychowanie. Optyka prawa polskiego i prawa kanonicznego, Kraków 2013, s. 85.

9 GUS, Metodologia badania budżetów gospodarstw domowych, Warszawa, 2011, s. 30.

10 T. Zalega, Gospodarstwo domowe jako podmiot konsumpcji, „Studia i Materiały” nr 1 (2007), s. 7.

11 Tamże, s. 10. 
gospodarstwo domowe najczęściej wyodrębnia się na podstawie dwóch kryteriów: wspólnego zamieszkiwania oraz wspólnego utrzymywania się. Z tego wynika, że może zaistnieć sytuacja, kiedy w jednym mieszkaniu będą zamieszkiwać dwa lub więcej gospodarstw domowych, jeśli tylko odpowiednie grupy osób lub pojedyncze osoby będą się utrzymywać oddzielnie. Stąd w badaniach statystycznych losuje się do próby mieszkania, w których (jeśli zachodzi taka sytuacja) bada się wszystkie gospodarstwa domowe ${ }^{12}$.

Instytucja gospodarstwa domowego wypełnia przede wszystkim funkcję ekonomiczną, którą można podzielić na funkcje produkcyjną i konsumpcyjną. Pierwsza polega na dostarczeniu do gospodarstwa domowego środków do realizacji konsumpcji poprzez wykonywanie pracy lub wykorzystanie kapitału, natomiast druga związana jest z organizowaniem konsumpcji (spożycia). Oprócz tej podstawowej funkcji gospodarstwo domowe wypełnia również funkcje społeczne, do których zaliczyć można funkcje reprodukcyjną i wychowawczą. Ten zakres funkcjonowania gospodarstwa wiąże się bezpośrednio z rodziną - podstawową komórką społeczną, na rzecz której podejmowane są decyzje ekonomiczne w ramach gospodarstwa domowego. Widzimy więc wyraźnie, że te dwa pojęcia, chociaż różne, odnoszą się często do tej samej grupy osób stanowiącej jednocześnie rodzinę i gospodarstwo domowe. Taka sytuacja daje możliwość całościowego spojrzenia na funkcjonowanie rodziny m.in. w kontekście dotykających jej zagrożeń.

\section{Wybrane aspekty sytuacji ekonomicznej gospodarstw domowych w Polsce}

Analiza sytuacji ekonomicznej ludności odbywa się poprzez badanie gospodarstw domowych. W związku z tym, że niniejsza praca skupia się na zagrożeniach życia rodzinnego w obszarze zagadnień ekonomicznych, uwaga zostanie skoncentrowana na tych typach biologicznych gospodarstwa domowego, które odnoszą się bezpośrednio do rodziny. W szczególności wyróżnia się następujące typy biologiczne gospodarstw domowych: małżeństwa bez dzieci (na utrzymaniu); małżeństwa $\mathrm{z}$ dziećmi na utrzymaniu, samotni rodzice $\mathrm{z}$ dziećmi na utrzymaniu, konkubinaty z dziećmi lub bez dzieci na utrzymaniu, które jednocześnie są uznawane za rodzinne gospodarstwa domowe.

W celu przedstawienia sytuacji ekonomicznej tych gospodarstw domowych wykorzystane zostaną dane z badania budżetów gospodarstw domowych przeprowadzanego corocznie przez GUS oraz dane z badania „Diagnoza społeczna”

$12 \quad$ Metodologia..., dz. cyt., s. 11. 
z 2013 roku. Podkreślić należy również, że ocena sytuacji ekonomicznej w gospodarstwach domowych, a więc i stopnia zagrożenia życia rodzinnego w zakresie ekonomicznym może być dokonywana na podstawie informacji natury subiektywnej lub obiektywnej. Obydwa te podejścia nie wykluczają się wzajemnie i w wielu przypadkach należy traktować je komplementarnie i równorzędnie.

Syntetyczną informację o sytuacji ekonomicznej gospodarstwa domowego daje odpowiedź na pytanie o stopień trudności „wiązania końca z końcem” przy uzyskiwanym aktualnie dochodzie. Takie pytanie jest obecne w badaniach budżetów gospodarstw domowych, jak również w „Diagnozie Społecznej”. W tabeli 1. zaprezentowano udziały gospodarstw domowych ze względu na stopień wystarczalności dochodów w układzie typu biologicznego.

Tabela 1. Udziały gospodarstw domowych ze względu na stopień trudności „wiązania końca $\mathrm{z}$ końcem" (w \%) oraz poziom dochodu ekwiwalentnego w układzie typu biologicznego gospodarstwa domowego

\begin{tabular}{|c|c|c|c|c|c|c|}
\hline \multirow{2}{*}{$\begin{array}{c}\text { Typ } \\
\text { gospodarstwa }\end{array}$} & \multicolumn{5}{|c|}{ Jak gospodarstwo „wiąże koniec z końcem”? } & \multirow{2}{*}{$\begin{array}{l}\text { Dochód } \\
\text { ekwiwa- } \\
\text { lentny }\end{array}$} \\
\hline & $\begin{array}{l}\text { z wielká } \\
\text { trudnością }\end{array}$ & $\begin{array}{l}\mathrm{z} \text { trud- } \\
\text { nością }\end{array}$ & $\begin{array}{l}\text { z pewná } \\
\text { trudnością }\end{array}$ & $\begin{array}{l}\text { raczej } \\
\text { łatwo }\end{array}$ & łatwo & \\
\hline $\begin{array}{l}\text { małżeństwa } \\
\text { bez dzieci }\end{array}$ & 10,50 & 15,76 & 35,60 & 29,32 & 8,82 & 1999,35 \\
\hline $\begin{array}{l}\text { małżeństwa } \\
\text { z } 1 \text { dzieckiem }\end{array}$ & 10,58 & 16,04 & 37,31 & 29,04 & 7,03 & 1883,58 \\
\hline $\begin{array}{l}\text { małżeństwa } \\
\text { z } 2 \text { dzieci }\end{array}$ & 10,78 & 16,61 & 40,31 & 26,62 & 5,68 & 1728,19 \\
\hline $\begin{array}{l}\text { małżeństwa } \\
\text { z 3+ dzieci }\end{array}$ & 22,08 & 26,11 & 31,09 & 16,86 & 3,86 & 1298,01 \\
\hline $\begin{array}{l}\text { konkubinat } \\
\text { bez dzieci }\end{array}$ & 15,89 & 13,20 & 34,99 & 31,75 & 4,18 & 2256,01 \\
\hline $\begin{array}{l}\text { konkubinat } \\
\text { z dziećmi }\end{array}$ & 24,58 & 16,68 & 28,93 & 23,64 & 6,16 & 1804,24 \\
\hline $\begin{array}{l}\text { rodziny } \\
\text { niepełne }\end{array}$ & 28,93 & 23,15 & 30,47 & 14,63 & 2,83 & 1381,55 \\
\hline wielorodzinne & 13,62 & 17,63 & 42,99 & 21,74 & 4,01 & 1495,34 \\
\hline $\begin{array}{l}\text { nierodzinne } \\
\text { jednoosobowe }\end{array}$ & 24,43 & 22,21 & 30,73 & 17,53 & 5,11 & 1664,04 \\
\hline $\begin{array}{l}\text { nierodzinne } \\
\text { wieloosobowe }\end{array}$ & 21,08 & 11,15 & 36,14 & 29,60 & 2,03 & 1420,50 \\
\hline Ogółem & 17,01 & 18,85 & 35,09 & 23,32 & 5,73 & 1714,66 \\
\hline
\end{tabular}

Źródło: obliczenia własne na podstawie danych z badania „Diagnoza Społeczna 2013”. 
W każdym przypadku najczęściej wskazywaną sytuacją jest doświadczanie pewnych trudności przy zaspokajaniu minimalnie wystarczającego poziomu potrzeb poprzez aktualnie dostępny dochód. Wśród małżeństw posiadających na utrzymaniu troje lub większą liczbę dzieci można zaobserwować istotny wzrost udziału tych gospodarstw domowych, które doświadczają trudności lub wielkie trudności w zaspokojeniu podstawowych potrzeb. Warto zauważyć, że najczęściej na wielkie trudności w zaspokajaniu potrzeb wskazują gospodarstwa rodzin niepełnych. W tym przypadku ponad 50\% gospodarstw utożsamiło swoją sytuację ekonomiczną z dwiema pierwszymi kategoriami. W ostatniej kolumnie tabeli 1. zawarto dane na temat poziomu dochodu ekwiwalentnego ${ }^{13}$. Biorąc więc po uwagę zróżnicowanie kosztów utrzymania gospodarstw o różnym składzie demograficznym, najniższym dochodem charakteryzują się gospodarstwa małżeństw wielodzietnych. Dochód ten jest wyraźnie mniejszy niż gospodarstw małżeństw bezdzietnych i z liczbą dzieci nie większą niż dwoje. Jest on również mniejszy niż dochód w rodzinach niepełnych, które subiektywnie postrzegały swoją sytuację dochodową gorzej niż rodziny wielodzietne. Warto zauważyć, że dochód ekwiwalentny może być miernikiem dobrobytu gospodarstw domowych. Z tego wynika, że wychowywanie większej liczby dzieci łączy się ze znacznym spadkiem dobrobytu w tych gospodarstwach.

W tabeli 2. zestawiono udziały gospodarstw domowych ze względu na sposób gospodarowania dochodem.

Tabela 2. Udziały gospodarstw domowych ze względu na sposób gospodarowania dochodem (w \%) w układzie typu biologicznego gospodarstwa domowego

\begin{tabular}{|l|c|c|c|c|}
\hline \multirow{2}{*}{$\begin{array}{c}\text { Typ } \\
\text { gospodarstwa }\end{array}$} & \multicolumn{4}{|c|}{ Sposób gospodarowania dochodem } \\
\cline { 2 - 5 } & $\begin{array}{c}\text { Starcza } \\
\text { na wszystko }\end{array}$ & $\begin{array}{c}\text { Żyjemy } \\
\text { oszczędnie }\end{array}$ & $\begin{array}{c}\text { Pieniędzy } \\
\text { starcza na naj- } \\
\text { tańsze jedzenie }\end{array}$ & $\begin{array}{c}\text { Nie starcza } \\
\text { nawet na najtań- } \\
\text { sze jedzenie }\end{array}$ \\
\hline $\begin{array}{l}\text { małżeństwa } \\
\text { bez dzieci }\end{array}$ & 24,85 & 61,09 & 13,42 & 0,64 \\
\hline
\end{tabular}

13 Dochody ekwiwalentne uzyskuje się dzieląc dochód gospodarstwa domowego przez liczbę jednostek ekwiwalentnych, które z kolei wyznacza się na podstawie skali ekwiwalentności. Skale te pozwalają w porównaniach poziomu dochodów uwzględnić zróżnicowanie gospodarstw domowych ze względu na cechy społeczno-demograficzne. W literaturze przedmiotu zaproponowano wiele metod estymacji skal ekwiwalentności. W niniejszym opracowaniu wykorzystano dochody ekwiwalentne obliczone na podstawie skali wyznaczonej w ramach badania „Diagnoza Społeczna”, której opis można znaleźć w: Diagnoza Społeczna 2013. Warunki i jakość życia Polaków. Raport, red. J. Czapiński., T. Panek, Warszawa 2013, s. 462-463. 


\begin{tabular}{|c|c|c|c|c|}
\hline \multirow{2}{*}{$\begin{array}{c}\text { Typ } \\
\text { gospodarstwa }\end{array}$} & \multicolumn{4}{|c|}{ Sposób gospodarowania dochodem } \\
\hline & $\begin{array}{c}\text { Starcza } \\
\text { na wszystko }\end{array}$ & $\begin{array}{c}\text { Żyjemy } \\
\text { oszczędnie }\end{array}$ & $\begin{array}{c}\text { Pieniędzy } \\
\text { starcza na naj- } \\
\text { tańsze jedzenie }\end{array}$ & $\begin{array}{c}\text { Nie starcza } \\
\text { nawet na najtań- } \\
\text { sze jedzenie }\end{array}$ \\
\hline $\begin{array}{l}\text { małżeństwa } \\
\text { z } 1 \text { dzieckiem }\end{array}$ & 25,85 & 58,84 & 14,87 & 0,44 \\
\hline $\begin{array}{l}\text { małżeństwa } \\
\text { z } 2 \text { dzieci }\end{array}$ & 22,37 & 61,86 & 14,82 & 0,95 \\
\hline $\begin{array}{l}\text { małżeństwa } \\
\text { z 3+ dzieci }\end{array}$ & 13,60 & 57,54 & 26,99 & 1,87 \\
\hline $\begin{array}{l}\text { konkubinat } \\
\text { bez dzieci }\end{array}$ & 29,09 & 53,35 & 15,01 & 2,56 \\
\hline $\begin{array}{l}\text { konkubinat } \\
\text { z dziećmi }\end{array}$ & 23,28 & 44,19 & 29,06 & 3,46 \\
\hline $\begin{array}{l}\text { rodziny } \\
\text { niepełne }\end{array}$ & 12,03 & 56,24 & 28,93 & 2,80 \\
\hline wielorodzinne & 15,47 & 65,75 & 18,09 & 0,69 \\
\hline $\begin{array}{l}\text { nierodzinne } \\
\text { jednoosobowe }\end{array}$ & 16,66 & 53,27 & 26,34 & 3,73 \\
\hline $\begin{array}{l}\text { nierodzinne } \\
\text { wieloosobowe }\end{array}$ & 26,45 & 53,14 & 19,63 & 0,79 \\
\hline Ogółem & 20,16 & 58,22 & 19,90 & 1,72 \\
\hline
\end{tabular}

Źródło: obliczenia własne na podstawie danych z badania „Diagnoza Społeczna 2013”.

Posiadanie dzieci na utrzymaniu zarówno w przypadku małżeństw, jak i rodzin niepełnych łączy się z relatywnie rzadką sytuacją, że dochodów w gospodarstwie domowym starcza na wszystko. Warto zwrócić uwagę, że w przypadku konkubinatów z dziećmi procent tego typu gospodarstw domowych jest porównywalny z odpowiednim udziałem odnoszącym się do małżeństw z niewielką liczbą dzieci. Z drugiej strony, relatywnie wysoki procent wśród tych gospodarstw wskazuje na kłopoty z zaspokojeniem podstawowych potrzeb. Ta sytuacja wskazuje na duże zróżnicowanie tego typu gospodarstw domowych. Jedną grupę mogą stanowić konkubinaty osób całkiem majętnych, którzy wraz ze zmianami kulturowymi w społeczeństwie wybrały taki typ związku, który nie zakłada formalnych ograniczeń (np. co do rozstania). W przypadku tego typu konkubinatów można przypuszczać, że charakteryzują się one mniejszą liczbą dzieci i dotyczą osób młodych częściej, niż ma to miejsce w przypadku małżeństw. Mniejsza liczba dzieci i nieco inne potrzeby młodszych osób mogą skutkować wysokim procentem tych gospodarstw konkubinackich, w których dochodów starcza na wszystko. Drugą grupę stanowią gospodarstwa osób nie- 
zamożnych, których nieformalny związek może wynikać z trudnych doświadczeń życiowych. Relatywnie duży procent gospodarstw doświadczających trudności w zakupie podstawowych produktów obserwujemy również w przypadku gospodarstw osób samotnych. Często są to osoby starsze (wdowy lub wdowcy), których źródłem utrzymania może być niewysoka renta lub emerytura, a które znaczną część swojego budżetu przeznaczają np. na leczenie. Taki obraz zagrożenia ubóstwem tej części społeczeństwa znajduje również potwierdzenie w wynikach zawartych w tabeli 1 .

W tabeli 3. pokazano kształtowanie się struktury odpowiedzi na pytanie o zaleganie z opłatami za czynsz oraz opłatami za energię. Poza potrzebami żywnościowymi te dwa rodzaje płatności wskazują na trudności w realizacji innej podstawowej potrzeby, jaką jest zamieszkanie.

Tabela 3. Udziały gospodarstw domowych ze względu na fakt zalegania z opłatami (w \%) w układzie typu biologicznego gospodarstwa domowego

\begin{tabular}{|c|c|c|c|c|c|c|}
\hline \multirow{2}{*}{$\begin{array}{c}\text { Typ } \\
\text { gospodarstwa }\end{array}$} & \multicolumn{3}{|c|}{ Zalega z opłatami za czynsz } & \multicolumn{3}{|c|}{ Zalega $\mathrm{z}$ opłatami za energię } \\
\hline & $\mathrm{Nie}$ & $<6 \mathrm{~m}-\mathrm{cy}$ & $>6 \mathrm{~m}-\mathrm{cy}$ & $\mathrm{Nie}$ & $<6 \mathrm{~m}-\mathrm{cy}$ & $>6 \mathrm{~m}-\mathrm{cy}$ \\
\hline $\begin{array}{l}\text { małżeństwa } \\
\text { bez dzieci }\end{array}$ & 96,30 & 3,03 & 0,67 & 98,15 & 1,43 & 0,41 \\
\hline $\begin{array}{l}\text { małżeństwa } \\
\text { z } 1 \text { dzieckiem }\end{array}$ & 95,77 & 3,83 & 0,41 & 97,01 & 2,89 & 0,11 \\
\hline $\begin{array}{l}\text { małżeństwa } \\
\text { z } 2 \text { dzieci }\end{array}$ & 94,59 & 4,61 & 0,80 & 97,07 & 2,82 & 0,11 \\
\hline $\begin{array}{l}\text { małżeństwa } \\
\text { z 3+ dzieci }\end{array}$ & 87,05 & 11,38 & 1,57 & 91,78 & 7,35 & 0,87 \\
\hline $\begin{array}{l}\text { konkubinat } \\
\text { bez dzieci }\end{array}$ & 86,38 & 10,40 & 3,22 & 94,59 & 4,27 & 1,14 \\
\hline $\begin{array}{l}\text { konkubinat } \\
\text { z dziećmi }\end{array}$ & 76,59 & 16,42 & 6,99 & 85,49 & 13,75 & 0,76 \\
\hline $\begin{array}{l}\text { rodziny } \\
\text { niepełne }\end{array}$ & 85,94 & 11,03 & 3,03 & 91,43 & 7,69 & 0,87 \\
\hline wielorodzinne & 90,61 & 6,17 & 3,21 & 95,30 & 4,42 & 0,28 \\
\hline $\begin{array}{l}\text { nierodzinne } \\
\text { jednoosobowe }\end{array}$ & 93,40 & 4,57 & 2,03 & 95,60 & 3,72 & 0,68 \\
\hline $\begin{array}{l}\text { nierodzinne } \\
\text { wieloosobowe }\end{array}$ & 94,96 & 3,59 & 1,46 & 96,68 & 2,86 & 0,46 \\
\hline Ogółem & 92,86 & 5,56 & 1,58 & 95,64 & 3,89 & 0,46 \\
\hline
\end{tabular}

Źródło: obliczenia własne na podstawie danych z badania „Diagnoza Społeczna 2013”. 
Okazuje się, że największe kłopoty z opłacaniem czynszu i rachunków za energię mają gospodarstwa konkubinackie z dziećmi na utrzymaniu, a następnie rodziny niepełne i wielodzietne. Mogłoby nieco zaskakiwać to, że konkubinaty z dziećmi i bez dzieci na utrzymaniu w odniesieniu do analogicznych gospodarstw małżeńskich mają większe kłopoty z opłacaniem podstawowych zobowiązań, zwłaszcza w kontekście wyników z tabeli 2., gdzie pokazano relatywnie duży udział tego typu gospodarstw, w których wielkość dochodu starcza na wszystko. Jednak w świetle uwag poczynionych powyżej, a odnoszących się do zróżnicowania gospodarstw konkubinackich, taka sytuacja ma swoje realne uzasadnienie.

W tabeli 4. przedstawiono udziały gospodarstw domowych doświadczających trudności życia codziennego w przedstawionych poniżej obszarach. Wystąpienie danego zjawiska lub jego brak traktuje się często jako symptom gorszej lub złej sytuacji ekonomicznej czy materialnej gospodarstwa domowego. Do symptomów zubożenia gospodarstw domowych zaliczono w niniejszej pracy:

- sytuację występowania w gospodarstwie co najmniej jednej osoby bezrobotnej;

- sytuację, gdy w gospodarstwie domowym brakuje pieniędzy na żywność (na zakup żywności przynajmniej z jednej z czterech grup żywnościowych);

- sytuację, gdy gospodarstwo domowe nie oszczędza;

- braki w wyposażeniu gospodarstwa w dobra trwałego użytku (brakuje co najmniej czterech z siedmiu elementów, takich jak.: pralka automatyczna, zmywarka, kuchenka mikrofalowa, telewizor, komputer stacjonarny, komputer niestacjonarny, samochód);

- braki w wyposażeniu mieszkania w instalacje (brakuje przynajmniej jednego z czterech rodzajów instalacji, tj. wodociągu, ustępu spłukiwanego, łazienki z prysznicem lub ciepłej wody);

- niewielka powierzchnia mieszkania przypadająca na osobę.

Tabela 4. Udziały gospodarstw domowych ze względu na symptomy zagrożenia złą sytuacją ekonomiczną (w \%) w układzie typu biologicznego gospodarstwa domowego

\begin{tabular}{|l|c|c|c|c|c|c|}
\hline $\begin{array}{c}\text { Typ } \\
\text { gospodarstwa }\end{array}$ & $\begin{array}{c}\text { Są bez- } \\
\text { robotni }\end{array}$ & $\begin{array}{c}\text { Brakuje na } \\
\text { żywność }\end{array}$ & $\begin{array}{c}\text { Brak } \\
\text { oszczędności }\end{array}$ & $\begin{array}{c}\text { Braki w wy- } \\
\text { posażeniu }\end{array}$ & $\begin{array}{c}\text { Braki w in- } \\
\text { stalacjach }\end{array}$ & $\begin{array}{c}\text { Pow. } \\
\text { mieszkania }\end{array}$ \\
\hline $\begin{array}{l}\text { małżeństwa } \\
\text { bez dzieci }\end{array}$ & 6,34 & 4,72 & 49,54 & 22,30 & 18,87 & 33,50 \\
\hline $\begin{array}{l}\text { małżeństwa } \\
\text { z 1 dzieckiem }\end{array}$ & 16,31 & 4,03 & 53,08 & 7,78 & 17,16 & 24,88 \\
\hline $\begin{array}{l}\text { małżeństwa } \\
\text { z 2 dzieci }\end{array}$ & 19,55 & 4,05 & 58,85 & 3,82 & 17,25 & 21,05 \\
\hline
\end{tabular}




\begin{tabular}{|l|c|c|c|c|c|c|}
\hline \multicolumn{1}{|c|}{$\begin{array}{c}\text { Typ } \\
\text { gospodarstwa }\end{array}$} & $\begin{array}{c}\text { Są bez- } \\
\text { robotni }\end{array}$ & $\begin{array}{c}\text { Brakuje na } \\
\text { żywność }\end{array}$ & $\begin{array}{c}\text { Brak } \\
\text { oszczędności }\end{array}$ & $\begin{array}{c}\text { Braki w wy- } \\
\text { posażeniu }\end{array}$ & $\begin{array}{c}\text { Braki w in- } \\
\text { stalacjach }\end{array}$ & $\begin{array}{c}\text { Pow. } \\
\text { mieszkania }\end{array}$ \\
\hline $\begin{array}{l}\text { małżeństwa } \\
\text { z 3+dzieci }\end{array}$ & 26,01 & 7,58 & 68,93 & 6,92 & 25,02 & 17,39 \\
\hline $\begin{array}{l}\text { konkubinat } \\
\text { bez dzieci }\end{array}$ & 18,71 & 10,32 & 58,76 & 16,45 & 13,80 & 23,36 \\
\hline $\begin{array}{l}\text { konkubinat } \\
\text { z dziećmi }\end{array}$ & 43,47 & 6,82 & 67,11 & 18,54 & 25,33 & 18,58 \\
\hline $\begin{array}{l}\text { rodziny } \\
\text { niepełne }\end{array}$ & 17,84 & 11,29 & 71,08 & 28,45 & 27,34 & 26,04 \\
\hline $\begin{array}{l}\text { wielorodzinne } \\
\text { nierodzinne } \\
\text { jednoosobowe }\end{array}$ & 31,49 & 5,20 & 62,74 & 6,67 & 22,07 & 19,49 \\
\hline $\begin{array}{l}\text { nierodzinne } \\
\text { wieloosobowe }\end{array}$ & 11,96 & 8,95 & 66,24 & 35,15 & 30,60 & 26,69 \\
\hline Ogółem & 14,59 & 6,93 & 59,39 & 23,86 & 22,07 & 31,19 \\
\hline
\end{tabular}

Źródło: obliczenia własne na podstawie danych z badania „Diagnoza Społeczna 2013”.

Wraz ze wzrostem liczby dzieci w małżeństwie narasta również problem bezrobocia, jednak najwyższy jego poziom można zaobserwować w przypadku konkubinatów z dziećmi. Co ciekawe, w gospodarstwach konkubinatów bezdzietnych procent takich gospodarstw, w których zamieszkują osoby bezrobotne, jest stosunkowo niewielki i wyraźnie kontrastuje z gospodarstwami tego typu posiadającymi dzieci. Ponadto stosunkowo wysoki poziom bezrobocia obserwuje się również w gospodarstwach wielorodzinnych. W przypadku braku środków finansowych na zakup żywności znowu małżeństwa wielodzietne wyraźnie częściej odczuwają tę dolegliwość niż rodziny bezdzietne lub z co najwyżej dwójką dzieci. Najbardziej problem ten dotyka rodzin niepełnych i konkubinatów bez dzieci. Dosyć podobną sytuację obserwujemy w przypadku częstości występowania braków oszczędności w gospodarstwie. Wzrost liczby dzieci wiąże się z mniejszymi możliwościami oszczędzania, jednak najbardziej taka sytuacja dotyczy rodzin niepełnych. Braki w wyposażeniu mieszkania w wybrane dobra trwałego użytku oraz w podstawowe instalacje w dużej mierze dotyczą gospodarstw małżeństw bez dzieci na utrzymaniu, a jeszcze bardziej gospodarstw jednoosobowych. W obydwu przypadkach można przypuszczać, że często takie gospodarstwa składają się z osób starszych, które nie przykładają tak dużej wagi do zapewnienia sobie nowoczesnych warunków życia. Tak więc niekoniecznie jedynie brak środków finansowych musi być przyczyną braków w wyposażeniu tych gospodarstw domowych. W przypadku małżeństw z dziećmi można zauważyć rosnący udział 
tych gospodarstw, w których takie braki są obserwowane. W szczególny sposób dotyczą one również rodzin niepełnych i gospodarstw konkubinatów. Na koniec warto zwrócić uwagę na prosty wskaźnik zaspokojenia potrzeb mieszkaniowych, jakim jest powierzchnia mieszkania na osobę. Najniższe wartości odnoszą się do rodzin wielodzietnych (małżeństw oraz konkubinatów z dziećmi na utrzymaniu). W tej sytuacji można przypuszczać, że zajmowane przez rodziny wielodzietne mieszkania są przeludnione ${ }^{14}$.

Na koniec rozważań o sytuacji ekonomicznej gospodarstw domowych w Polsce uwaga zostanie pokrótce skupiona na problemie ubóstwa w Polsce. W przypadku klasycznej analizy ubóstwa niezbędne jest określenie granicznego dochodu, poniżej którego dane gospodarstwo uznane zostanie za ubogie. Taki dochód zwykło się nazywać linią ubóstwa. Metod wyznaczania linii ubóstwa jest wiele ${ }^{15}$ i niestety nie ma wśród nich jednej powszechnie akceptowalnej. W tabeli 5. przedstawiono wartości tzw. minimum egzystencji i minimum socjalnego - dwóch linii ubóstwa wyznaczanych przez Instytut Pracy i Spraw Socjalnych od lat 80. XX wieku.

Tabela 5. Poziom minimum egzystencji i minimum socjalnego średniorocznie w 2013 roku

\begin{tabular}{|c|c|c|c|c|c|c|c|}
\hline \multirow{3}{*}{ 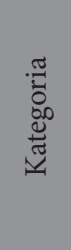 } & \multicolumn{7}{|c|}{ Granica ubóstwa } \\
\hline & \multicolumn{5}{|c|}{ Gospodarstwa pracownicze } & \multicolumn{2}{|c|}{$\begin{array}{c}\text { Gospodarstwa } \\
\text { emeryckie }\end{array}$} \\
\hline & $\begin{array}{c}\text { 1-osob. } \\
(\mathrm{K}+\mathrm{M}) / 2\end{array}$ & $\begin{array}{c}\text { 2-osob. } \\
\mathrm{K}+\mathrm{M}\end{array}$ & $\begin{array}{c}\text { 3-osob. } \\
\mathrm{K}+\mathrm{M}+\mathrm{Dm}\end{array}$ & $\begin{array}{c}\text { 3-osob. } \\
\mathrm{K}+\mathrm{M}+\mathrm{Ds}\end{array}$ & $\begin{array}{c}\text { 4-osob. } \\
\mathrm{K}+\mathrm{M}+ \\
\mathrm{Dm}+\mathrm{Ds}\end{array}$ & $\begin{array}{c}1 \text {-osob. } \\
(\mathrm{K}+\mathrm{M}) / 2\end{array}$ & $\begin{array}{c}\text { 2-osob. } \\
\mathrm{K}+\mathrm{M}\end{array}$ \\
\hline $\mathrm{ME}$ & 541,91 & 911,80 & 1319,04 & 1442,69 & 1850,85 & 513,87 & 855,72 \\
\hline MS & 1061,27 & 1761,07 & 2692,97 & 2787,04 & 3449,95 & 1062,45 & 1778,44 \\
\hline
\end{tabular}

Źródło: IPiSS (https://www.ipiss.com.pl, czerwiec 2015).

14 Definicja mieszkania przeludnionego wg Eurostatu jest nieco inna. Wskazuje się w niej, ile pokoi powinno przypadać na gospodarstwo domowe w zależności od jego składu (zob. http://ec.europa.eu/eurostat/statistics-explained/index.php/Glossary:Overcrowding rate, czerwiec 2015). Można jednak przypuszczać, że mała powierzchnia mieszkania przypadająca na osobę w gospodarstwie domowym wiązać się będzie ze spełnieniem w większości przypadków kryterium, według którego mieszkanie można uznać za przeludnione.

15 T. Panek, Ubóstwo, wykluczenie społeczne i nierówności. Teoria i praktyka pomiaru, Warszawa 2011, s. 23-42. 
Wykres 1. Zagrożenie ubóstwem w Polsce w latach 2005-2013 według przyjętych w danym roku granic ubóstwa

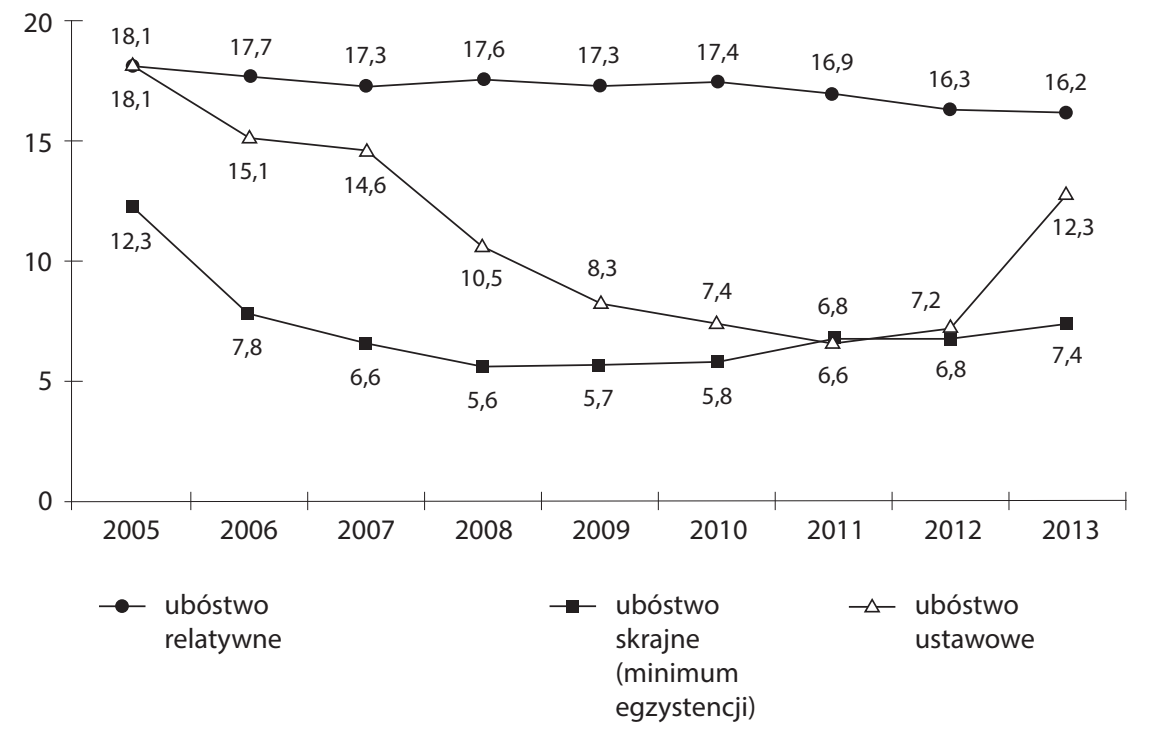

Źródło: Ubóstwo ekonomiczne w Polsce w 2013 r. - Informacja sygnalna, GUS, Warszawa 2014.

Wartości obydwu minimów zostały określone dla siedmiu typów gospodarstw domowych: pięciu pracowniczych i dwóch emeryckich. Oznaczenia Klub M odnoszą się do kobiet lub mężczyzn, natomiast Dm i Ds do dziecka młodszego i dziecka starszego ${ }^{16}$. Warto zauważyć niski poziom minimum egzystencji (biologicznego przetrwania) i wyraźnie wyższy poziom minimum socjalnego, zakładający przede wszystkim (oprócz zaspokojenia potrzeb podstawowych) utrzymanie więzi społecznych. Biorąc pod uwagę wysokość dochodu uprawniającego do świadczeń społecznych (uznawany często za ustawową linię ubóstwa), można stwierdzić, że jest on prawie dokładnie zgodny z minimum egzystencji dla gospodarstwa jednoosobowego (wynosi bowiem $542 \mathrm{zl}$ ), a dla gospodarstwa czteroosobowego kwota ta jest nawet niższa niż minimum egzystencji (1824 zł). Nasuwa się więc wniosek, że na pomoc państwa gospodarstwa domowe mogą liczyć jedynie wówczas, gdy ich ubóstwo jest już skrajnie niskie. Na wykresie 1. pokazano kształtowanie się zubożenia ludności w Polsce w latach 2005-2013 według przyjętych linii ubóstwa. Warto zwrócić uwagę na sys-

16 Więcej na ten temat można znaleźć na stronach IPiSS (https://www.ipiss.com.pl, czerwiec 2015). 
tematycznie opadający do 2012 roku procent ubogich według ustawowej linii ubóstwa. Taka sytuacja wynikała $\mathrm{z}$ długiego okresu braku waloryzowania progów dochodowych, co przy rosnących ogólnie dochodach w społeczeństwie powodowało spadek liczby osób ubogich. W 2013 roku określono wyższe (wspomniane wyżej) progi dochodowe, co automatycznie spowodowało wzrost ubóstwa społeczeństwa według tego podejścia.

Korzystając z wyliczeń GUS-u, w tabeli 6. zaprezentowano oszacowania tzw. stopy ubóstwa, mierzącej zasięg ubóstwa (zagrożenie ubóstwem) w układzie typu biologicznego gospodarstwa domowego. Wyniki te odnoszą się do trzech linii ubóstwa, uwidocznionych na wykresie 1. Wśród nich znajduje się jeszcze relatywna granica ubóstwa wyznaczana jako 50\% przeciętnego dochodu ekwiwalentnego, przy czym jako skalę ekwiwalentności przyjęto oryginalną skalę OECD. Zastosowaną ją również dla ubóstwa skrajnego (minimum egzystencji), co powoduje, że wartości stopy ubóstwa na rysunku 1. i w tabeli 6. dla minimum egzystencji i ustawowej granicy ubóstwa różnią się pomimo analogicznych poziomów wspomnianych linii ubóstwa.

Tabela 6. Zagrożenie ubóstwem według różnych linii ubóstwa w układzie typu biologicznego gospodarstwa domowego

\begin{tabular}{|c|c|c|c|}
\hline \multirow{2}{*}{$\begin{array}{l}\text { Typ gospodarstwa } \\
\text { domowego }\end{array}$} & \multicolumn{3}{|c|}{ osób w gospodarstwach domowych o wydatkach poniżej } \\
\hline & $\begin{array}{l}\text { minimum } \\
\text { egzystencji }\end{array}$ & $\begin{array}{l}\text { relatywnej granicy } \\
\text { ubóstwa }\end{array}$ & $\begin{array}{c}\text { ustawowej granicy } \\
\text { ubóstwa }\end{array}$ \\
\hline 1-osobowe & 2,5 & 6,1 & 2,6 \\
\hline \multicolumn{4}{|l|}{ małżeństwa: } \\
\hline $\begin{array}{l}\text { bez dzieci } \\
\text { na utrzymaniu }\end{array}$ & 1,9 & 5,3 & 1,8 \\
\hline z 1 dzieckiem & 2,4 & 6,9 & 3,9 \\
\hline z 2 dzieci & 4,7 & 12,1 & 9,9 \\
\hline z 3 dzieci & 10,2 & 23,1 & 21,8 \\
\hline z 4 dzieci i więcej & 22,8 & 46,7 & 49,8 \\
\hline $\begin{array}{l}\text { matka lub ojciec } \\
\text { z dziećmi } \\
\text { na utrzymaniu }\end{array}$ & 7,9 & 20,4 & 17,7 \\
\hline
\end{tabular}

Źródło: Ubóstwo ekonomiczne w Polsce w 2013 r. - Informacja sygnalna, GUS, Warszawa 2014. 
Wraz ze wzrostem liczby dzieci wychowywanych przez małżeństwo wzrasta zasięg ubóstwa, a najbardziej dotyka ono małżeństw z czworgiem i większą liczbą dzieci na utrzymaniu. W tej grupie gospodarstw domowych blisko $23 \%$ osób doświadcza skrajnego ubóstwa, a blisko połowa kwalifikuje się do uzyskania świadczeń z pomocy społecznej. Znamienne jest to, że samotni rodzice mają wyraźnie lepszą sytuację ekonomiczną niż wspomniane wyżej rodziny wielodzietne. Nie przecząc potrzebie wsparcia przez państwo rodzin niepełnych, warto zwrócić uwagę na zaniedbania państwa w ochronie i wsparciu wielodzietnych rodzin pełnych. Taka sytuacja powoduje zagrożenia w wymiarze zarówno indywidualnym, jak i społecznym. Indywidualnym, bo ubóstwo dotyka poszczególnych gospodarstw domowych i ich członków, a społecznym, ponieważ kształtuje obraz wielodzietności w połączeniu z wysokim zagrożeniem ubóstwem. Trudno więc oczekiwać, aby racjonalnie myślący małżonkowie decydowali się na więcej niż jedno dziecko, chyba że porzucą założenie racjonalności na rzecz innych motywów skłaniających ich do zakładania licznej rodziny. W szeroko rozumianym wsparciu rodzin wielodzietnych należy przejść od myślenia zakładającego interwencję państwa w sytuacji zagrożenia skrajnym ubóstwem do myślenia w kontekście inwestycji w przyszłość społeczeństwa polskiego. W tej optyce wsparcie państwa (społeczeństwa) powinno być udzielane (w jakimś być może zróżnicowanym zakresie) każdej rodzinie, a nie tylko tej, która jest na skraju nędzy. Jeśli wychowanie dzieci jest pracą społecznie użyteczną, to powinna ona być gratyfikowana niezależnie od tego, czy rodzina wielodzietna jest bardziej lub mniej majętna. Takie podejście spowodowałoby spadek ubożenia rodzin wielodzietnych i jednocześnie zachęcałoby młode małżeństwa do zakładania takich rodzin i poświęcenia się w większym wymiarze wychowaniu dzieci. Wszystkim nam zależy przecież, aby dzieci wychowywały się w rodzinach silnych i zdrowych również od strony ekonomicznej.

\section{Zakończenie}

Podsumowując, badania sytuacji ekonomicznej rodzin i ich gospodarstw domowych nie mogą być przeprowadzane w oderwaniu od innych aspektów życia i funkcjonowania rodziny. Niedostatki w sferze ekonomicznej nie prowadzą nieodwołalnie do patologizacji życia rodzinnego w takim czy innym wymiarze, ale są istotnym zagrożeniem dla sprawnego funkcjonowania rodziny.

Jak już wcześniej wspomniano, wysoki udział ubogich gospodarstw tworzonych przez rodziny wielodzietne nie jest pozytywnym przykładem i reklamą wielodzietności w Polsce, co w kontekście niepokojąco niskiej dzietności rodzi obawy o przyszłość demograficzną, społeczną i ekonomiczną państwa. 
W tej sytuacji nieodzowny staje się kompleksowy program wsparcia rodziny, a zwłaszcza rodziny wielodzietnej, traktujący to wsparcie jako inwestycję. Jak w przypadku każdej inwestycji, na początku należy ponieść pewne koszty, a korzyści będą osiągane w przyszłości. To oddalenie w czasie kosztów od korzyści może być dla rządów powoływanych na kadencje problemem, jeśli się założy, że efekty inwestycji mogą zbierać przeciwnicy polityczni. Niestety, jest to słabość polskiej klasy politycznej, wyrażająca się awersją do uczciwego rozliczenia swojej działalności, wskazania na zasługi innych, a nie wytykania tylko ich wad. W tej sytuacji trudno się spodziewać długofalowego i kompleksowego programu wspierania rodziny, który dzięki politycznemu kompromisowi miałby szansę realizacji w perspektywie kolejnych rządów. Jest to jedno z większych zagrożeń dla rodziny i przyszłej sytuacji społeczno-ekonomicznej państwa. Trzeba w końcu postawić na rodzinę.

\section{Bibliografia}

Dekret o apostolstwie świeckich Apostolicam actuositatem, [w:] Sobór Watykański II. Konstytucje, dekrety, deklaracje, Poznań 1986.

Diagnoza Społeczna 2013. Warunki i jakość życia Polaków. Raport, red. J. Czapiński, T. Panek, Warszawa 2013.

GUS, Gospodarstwa domowe i rodziny. Charakterystyka demograficzna. Narodowy Spis Powszechny Ludności i Mieszkań 2011, Warszawa 2014.

GUS, Metodologia badania budżetów gospodarstw domowych, Warszawa 2011.

Hantrais L., Bycie rodzina w Europie - raport, Rządowa Rada Ludnościowa, Biuletyn 50, Warszawa 2006.

Kroczek P., Wychowanie. Optyka prawa polskiego i prawa kanonicznego, Kraków 2013.

Leon XIII, enc. Rerum novarum.

Panek T., Ubóstwo, wykluczenie społeczne i nierówności. Teoria i praktyka pomiaru, Warszawa 2011.

Principles and Recommendations for Population and Housing Censuses, Revision 1, United Nations, New York, 1998, para. 2.63.

Zalega T., Gospodarstwo domowe jako podmiot konsumpcji, „Studia i Materiały” nr 1(2007). 